\title{
Sixth Amendment Limits on Collateral Uses of Uncounseled Convictions
}

The Sixth Amendment guarantees indigent criminal defendants a right to appointed counsel in federal cases that threaten their life or liberty, ${ }^{1}$ in state felony cases, ${ }^{2}$ and in state misdemeanor cases that result in imprisonment. ${ }^{3}$ When appointed counsel is denied in such cases, convictions are retroactively held unconstitutional.4 Until recently, such convictions could not be used for collateral purposes such as sentencing decisions, ${ }^{5}$ recidivist statutes, ${ }^{6}$ and impeachment. ${ }^{7}$

In Lewis v. United States, ${ }^{8}$ however, the Supreme Court permitted the collateral use of an unconstitutional uncounseled conviction. The Court allowed it to be counted as a prior conviction for purposes of a federal law that punished with imprisonment the possession of a gun by a convicted felon. ${ }^{9}$ Because the holding in Lewis appears inconsistent with earlier decisions that prohibited other collateral uses of such convictions, ${ }^{10}$ Lewis has been described as an aberration. ${ }^{11}$

This Note proposes a Sixth Amendment rule that strikes a compromise between the competing values underlying Lewis and other Sixth Amendment decisions, while still leaving the holdings of those cases intact. The proposed rule prohibits the collateral use of uncounseled convictions when there is a reasonable alternative means of advancing the government's interest. When there is no such alternative, the rule would permit the government to use uncounseled convictions collaterally (1) if no independent constitutional rights are themselves restricted and (2) if the government provides access to an application process that enables the individual to

1. Johnson v. Zerbst, 304 U.S. 458, 468 (1938).

2. Gideon v. Wainright, 372 U.S. $335,339-40,342,345$ (1963); see Scott v. Illinois, 440 U.S. 367,371 (1979).

3. Baldasar v. Illinois, 446 U.S. 222, 222-24 (1980) (per curiam); Scott v. Illinois, 440 U.S. 367, 373-74 (1979).

4. See, e.g., Kitchens v. Smith, 401 U.S. 847 (1971); Pickelsheimer v. Wainright, 375 U.S. 2 (1964).

5. United States v. Tucker, 404 U.S. 443, $448-49$ (1972).

6. Burgett v. Texas, 389 U.S. 109, 115-16 (1967).

7. Loper v. Beto, 405 U.S. 473, 483 (1972); Burgett v. Texas, 389 U.S. 109, 115 (1967).

8. 445 U.S. 55 (1980).

9. Id. at 65-67.

10. See, e.g., Loper v. Beto, 405 U.S. 473,483 (1972) (collateral use of unconstitutional uncounseled conviction to impeach defendant's credibility prohibited); Burgett v. Texas, 389 U.S. 109, 11516 (1967) (collateral use of unconstitutional uncounseled conviction to support prosecution of recidivism unconstitutional).

11. See Lewis v. United States, 445 U.S. 55, $71-72$ (1980) (Brennan, J., dissenting); Recent Cases, Constitutional Law: Sixth Amendment-Right to Counsel-Use of Prior Uncounseled Convictions, 14 AKRON L. REV. 155, 159-61 (1980). 
show why the uncounseled conviction should not be used or why its use should receive special consideration.

\section{The Underlying Sixth Amendment Right to Counsel}

In Johnson v. Zerbst, the Supreme Court recognized that without the assistance of counsel even the intelligent layman usually "lacks both the skill and knowledge adequately to prepare his defense, even though he have a perfect one." ${ }^{12}$ On the basis of this observation, ${ }^{13}$ Johnson held that the Sixth Amendment ${ }^{14}$ requires the federal government to appoint counsel for criminal defendants who are unable to obtain counsel themselves, who have not waived their constitutional right to counsel, and whose life or liberty is in jeopardy. ${ }^{15}$

Gideon v. Wainwright built on Johnson by holding that indigent criminal defendants' Sixth Amendment right to appointed counsel is a fundamental right necessary to ensure the right to a fair trial and the funda-

12. 304 U.S. 458,463 (1938). The Johnson opinion went on to quote from Powell v. Alabama to the effect that the

right to be heard would be, in many cases, of little avail if it did not comprehend the right to be heard by counsel. Even the intelligent and educated layman has small and sometimes no skill in the science of law. If charged with crime, he is incapable, generally, of determining for himself whether the indictment is good or bad. He is unfamiliar with the rules of evidence. Left without the aid of counsel he may be put on trial without a proper charge, and convicted upon incompetent evidence, or evidence irrelevant to the issue or otherwise inadmissible. . . . He requires the guiding hand of counsel at every step in the proceedings against him.

Id. at 463 (quoting Powell v. Alabama, 287 U.S. 45, 68-69 (1932)). These observations have supported the rationale of many later Sixth Amendment decisions. See, e.g., Argersinger v. Hamlin, 407 U.S. 25, 31, 32 \& n.3 (1972); Gideon v. Wainwright, 372 U.S. 335, 344-45 (1963).

13. The Johnson opinion ignored substantial evidence that the Framers of the Bill of Rights did not intend to have the Sixth Amendment include the right to appointed counsel. W. BEANEY, THE RIGHT TO COUNSEL IN AMERICAN COURTS 42, 44 (1955).

14. Prior to Johnson, the Supreme Court had not construed the Sixth Amendment to include the right of indigent defendants to have counsel appointed for them at government expense. $W$. BEANEY, supra note 13, at 32, 43-44; see Herman \& Thompson, Scott v. Illinois and the Right to Counsel: $A$ Decision in Search of a Doctrine? 17 AM. CRIM. L. REV. 71, $72-73$ (1979). One earlier Supreme Court case acknowledged the existence of a constitutional right to appointed counsel, albeit on due process grounds. In that case, the Court held that the appointment of counsel only on the morning of trial denied a fair trial to defendants whose conviction resulted in a death sentence. Powell v. Alabama, 287 U.S. 45, 56, 71 (1932).

The terms of the Sixth Amendment do not establish the right to appointed counsel. See U.S. CoNST. amend. VI ("In all criminal prosecutions, the accused shall enjoy the right . . to have the Assistance of Counsel for his defence.") In fact, it is doubtful that the Framers of the Bill of Rights intended the Sixth Amendment to guarantee any right other than the right of a criminal defendant in federal court to employ a lawyer to assist in his defense. Scott v. Illinois, 440 U.S. 367, 370 (1979) (citing W. BEANEY, supra note 13 , at 27-30).

15. 304 U.S. 458, 468 (1938); see W. BEANEY, supra note 13, at 42-53; Note, Argersinger v. Hamlin and the Collateral Use of Prior Misdemeanor Convictions of Indigents Unrepresented by Counsel at Trial, 35 OHIO ST. L.J. 168, 168 n.3 (1974). Because Johnson involved a felony conviction, some commentators suggest its holding is limited to felony cases, see Herman \& Thompson, supra note 14, at 73, but Johnson itself states otherwise, 304 U.S. at 463, 468, and it has not been limited by later cases. 
mental human rights of life and liberty. ${ }^{16}$ Gideon further held that the fundamental nature of the right to appointed counsel made it obligatory on the states through its incorporation in the due process clause of the Fourteenth Amendment. ${ }^{17}$

The Supreme Court halted the gradual expansion of the Sixth Amendment right to appointed counsel in Scott v. Illinois. ${ }^{18}$ Scott recognized that the Sixth Amendment, as incorporated in the Fourteenth Amendment, prohibits the imposition of a criminal sanction as severe as incarceration unless an indigent criminal defendant has been offered appointed counsel, regardless of the cost to the states. ${ }^{19}$ But, in an opinion that is inconsistent with the rationales of earlier decisions, ${ }^{20}$ though not with their holdings, the Scott Court held that the Sixth Amendment did not require states to appoint counsel for indigent misdemeanor defendants who were not to be punished with incarceration. ${ }^{21}$ In support of this result, the Court ob-

16. 372 U.S. $335,343-44$ (1973).

17. Id. at 342. The Gideon Court's discussion of the application of the Sixth Amendment to state criminal cases began with the observation that in federal courts the Sixth Amendment requires that counsel be provided for all criminal defendants who are unable to employ counsel. Id. at 340 (citing Johnson v. Zerbst, 304 U.S. 458 (1938)). The Court went on to agree with Betts v. Brady, 316 U.S. 455 (1972), "that a provision of the Bill of Rights which is 'fundamental and essential to a fair trial" is made obligatory upon the States by the Fourteenth Amendment," but overruled Betts as an "anachronism when handed down" for its holding that the Sixth Amendment right to appointed counsel was not a fundamental right essential to a fair trial. 372 U.S. at 342-45. The Betts approach of determining the right to appointed counsel on the basis of the special circumstances of the case, sec 316 U.S. at $471-73$, was thus firmly rejected. 372 U.S. at 339.

The majority opinion's broad language, and a disagreement in two of the concurring opinions about whether the decision fully incorporates the Sixth Amendment into the Fourteenth Amendment, resulted in some uncertainty over whether the decision was limited to its factual context. But the majority opinion suggests that such a limitation is inappropriate, 372 U.S. at 339-45; moreover, on the same day Gideon was decided, the Court vacated an uncounseled misdemeanor conviction and remanded it to the state court for reconsideration in light of Gideon. Patterson v. Warden, 372 U.S. 776 (1963). Various state and federal courts nevertheless split over Gideon's meaning, and several Supreme Court decisions referred to Gideon as applying to felony cases without raising the issue of whether it extended to other criminal cases as well. See, e.g., Scott v. Illinois, 440 U.S. 367, 371 (1979); Argersinger v. Hamlin, 407 U.S. 25, $31-32$ (1972); Burgett v. Texas, 389 U.S. 109, 114 (1967); cf. Scott v. Illinois, 440 U.S. 367, 378 (1979) (Brennan, J., dissenting) (Gideon extended to all criminal prosecutions).

18. 440 U.S. 367 (1979). For a thorough discussion of Scott, see Herman \& Thompson, supra note 14; Note, The Outer Limits of the Indigent's Right to Appointed Counsel, 5 U. DAYTON L. REV. 177 (1980); Note, Scott v. Illinois: The Right to Counsel Retreats, 41 U. PITT. L. REV. 647 (1980).

19. 440 U.S. $367,372-73$ (1979).

20. See supra pp. 1001-02.

21. 440 U.S. 367, 372-74 (1979). Although Scott "hold[s] that the Sixth and Fourteenth Amendments . . . require only that no indigent defendant be sentenced to a term of imprisonment unless the State has afforded him the right to . . . appointed counsel," 440 U.S. at 373-74, the opinion appears to accept Gideon as requiring counsel to be appointed for all indigent felony defendants, including those who are not imprisoned. Id. at 371, 373-74. Because the defendant in Gideon received a prison sentence, the Scott opinion is consistent with Gideon's results irrespective of whether the Scott rule affords Sixth Amendment protection to indigent felony defendants who are not imprisoned.

Scott is generally thought to apply only to state misdemeanor convictions. See Baldasar v. Illinois, 446 U.S. 222, 222 (1980) (per curiam) (Powell, J., dissenting); Note, Constitutional Law-Criminal Procedure-Right to Counsel-Indigent Misdemeanor Defendant Not Entitled to Court Appointed Attorney Unless Sentenced to Actual Confinement, Scott v. Illinois, 440 U.S. 367 (1979), 9 U. BALT. 
served that the Framers of the Bill of Rights intended the Sixth Amendment to guarantee only the right to retained counsel, ${ }^{22}$ that the incorporation of the Sixth Amendment in the Fourteenth Amendment has special difficulties because state laws regulate a broader range of human affairs than do federal laws, ${ }^{23}$ and that these differences justified the decision not to extrapolate further the already extended line of the right to appointed counsel. ${ }^{24}$

Scott then balanced the states' interests in the efficient administration of justice against criminal defendants' interests in having appointed counsel. To the extent Gideon suggested that indigent criminal defendants' interests automatically outweighed the government's interests, and that all indigent criminal defendants were therefore entitled to appointed counsel, Scott's reevaluation of governmental interests in determining the limits of the Sixth Amendment retroactively changed Gideon's rationale. But because the application of the Scott decision to the Gideon facts would not have altered Gideon's result, the Scott court was able to limit Gideon without overturning it. ${ }^{25}$

\section{Competing Views on Collateral Use of Uncounseled Convictions}

Until recently, collateral use of uncounseled convictions ${ }^{26}$ has generally been prohibited. ${ }^{27}$ In 1980, however, in Lewis v. United States, the Su-

L. REV. 453, 466 (1980). For a discussion of other areas of confusion generated by Scott, see Herman \& Thompson, supra note 14, at 91-95. For criticisms of Scott's inconsistency with prior rationales and opinions (albeit not their results), and its creation of an illogical boundary for the Sixth Amendment right to appointed counsel, see id. at 91-98; Note, The Outer Limits of the Indigent's Right to Counsel, supra note 18, at 181-86; Note, Scott v. Illinois, supra note 18, at 647, 655-61.

22. Scott v. Illinois, 440 U.S. 367,370 (1979).

23. Id. at 372 .

24. Id.

25. Scott follows Gideon in rejecting a balancing test that makes the right to counsel dependent upon the particular circumstances of each case. The fixed Sixth Amendment line drawn in Scott is less inclusive than the one suggested in Gideon, but both lines require appointment of counsel for indigent defendants such as the defendant in Gideon, who was imprisoned for a felony conviction.

26. "Uncounseled convictions" shall hereinafter refer to outstanding prior convictions that resulted from criminal proceedings in which the defendant was unable to obtain counsel for himself, did not waive his right to counsel, and did not have the assistance of counsel at the critical stages of prosecution. All such convictions are unconstitutional except for state misdemeanor convictions that are not punished with incarceration. See supra p. 1002.

Collateral use of uncounseled convictions resulting from state misdemeanors is constitutional for any purpose except for proceedings that result in imprisonment. Scott v. Illinois, 440 U.S. 367, 373 (1979). To avoid repetition, this exception should be considered implicit in subsequent references to the permitted uses of uncounseled convictions.

27. Note, supra note 15, at 176-82; see supra p. 1000 . Because criminal convictions are considered particularly reliable, see In re Winship, 397 U.S. 358 (1970) (guilt in criminal case must be proven beyond reasonable doubt); Brinegar v. United States, 338 U.S. 160, 174 (1949) (same), they are frequently used to provide information for a variety of collateral purposes, including sentencing decisions, recidivist statutes, revocation of probation or parole, denial of professional and occupational licenses, denial of government jobs, disenfranchisement, and prohibition of ownership of explosives. All fifty states and the federal government use criminal convictions for a number of collateral pur- 
preme Court permitted the collateral use of an uncounseled felony conviction, without overruling previous Sixth Amendment decisions. ${ }^{28}$ The resultant doctrinal confusion has yet to be resolved.

\section{A. The Traditional View}

Burgett v. Texas ${ }^{29}$ reflects the traditional view of the collateral use of uncounseled convictions. According to the Court in Burgett, permitting a conviction deficient under Gideon "to be used against a person either to support guilt or enhance punishment for another offense ... erode[s] the principle of that case" 30 and makes the accused "suffe[r] anew from the deprivation of [his] Sixth Amendment right." ${ }^{31}$ The Court thus held that an uncounseled conviction could not count as a prior conviction for purposes of a recidivist statute that operated to enhance jail sentences. ${ }^{32}$ For similar reasons, United States v. Tucker barred the inclusion of an uncounseled conviction in the set of factors to be considered by a judge when sentencing a defendant for a subsequent crime, ${ }^{33}$ and Loper v. Beto held that an uncounseled conviction could not be used to impeach a defendant's

poses. See Argersinger v. Hamlin, 407 U.S. 25, 48 \& n.11 (1972) (Powell, J., concurring); Duke, The Right to Appointed Counsel; Argersinger and Beyond, 12 AM. CRIM. L. REV. 601, 615-17 (1975); Project, The Collateral Consequences of a Criminal Conviction, 23 VAND. L. REV. 929, passim (1970).

28. 445 U.S. 55 (1980).

29. 389 U.S. 109 (1967).

30. Permitting collateral use would erode the right to counsel because the government might have less incentive to provide counsel in the first proceeding: even though Gideon and Scott already strongly deter the government from denying counsel where the resulting conviction is unconstitutional in the first instance, the ban on collateral use would deter the government from seeking uncounseled convictions constitutional under Scott that the government could use collaterally in proceedings resulting in imprisonment. The ban on collateral use also prevents the moral injustice of allowing the government to benefit from its previous wrong-deprivation of the right to appointed counsel in a prior case. The courts in fact have protected individuals from prosecution based on an uncounseled conviction. E.g., Baldasar v. Illinois, 446 U.S. 222 (1980) (per curiam); City of Monroe v. Fincher, 305 So. 2d 108 (La. 1974); cf. Alexander v. State, 258 Ark. 633, 527 S.W.2d 927 (1975) (uncounseled conviction not basis for revocation of suspended sentence). Contra Aldrighetti v. State, 507 S.W.2d 770 (1974) (uncounseled conviction not punished with incarceration can be used to impeach defendant or enhance prison term); State v. McGrew, 127 N.J. Super. 327, 317 A.2d 390 (1974) (uncounseled conviction not punished with incarceration can support conviction under recidivist statute requiring mandatory incarceration).

31. Burgett v. Texas, 389 U.S. 109, 115 (1967).

32. Id. The many different types of recidivist statutes (also called enhancement, habitual criminal and repeat offender statutes) generally upgrade the classification or punishment for specified types of future criminal convictions. The Texas statute whose application was invalidated in Burgett automatically raised the punishment for a non-capital felony conviction to the highest punishment ordinarily possible if it was proved that the defendant had already been convicted of a similar offense. TEX. PENAL CODE art. 62 (1952). See generally Note, supra note 15, at 176-79 (discussing use of invalid convictions to enhance punishment).

33. 404 U.S. $443,446,449$ (1972) (affirming decision of circuit court to remand "the case to the District Court for resentencing "without consideration of any prior convictions which are invalid under Gideon v. Wainwright' "); accord, Lewis v. United States, 445 U.S. 55, 60 (1980) (dictum). 
credibility. ${ }^{34}$

\section{B. The Lewis Court's View}

The Supreme Court first upheld the collateral use of an uncounseled conviction in Lewis v. United States. ${ }^{35}$ Lewis held that an uncounseled felony conviction that was deficient under Gideon could constitutionally be counted as a prior conviction for purposes of a federal statute that made it a crime for convicted felons to possess a gun. ${ }^{36}$

The Court noted that the firearm disability did not violate constitutional equal protection requirements because Congress had "some 'rational basis' for the statutory distinctions made," ${ }^{\prime 37}$ because the disability was not "based upon constitutionally suspect criteria,"38 and because it did "not trench upon constitutionally protected liberties." 39 The Sixth Amendment, the Court continued, allows the government to use an uncounseled conviction collaterally to impose an essentially civil disability when the government's use of the conviction depends only on the existence of the conviction, and not on its reliability. ${ }^{40}$ The Lewis majority concluded that the Sixth Amendment allows the government to enforce such a disability with criminal sanctions because in so doing the government does not "support guilt or enhance punishment" for a disability that was irrationally

34. 405 U.S. 473, 483 (1972); accord Lewis v. United States, 445 U.S. 55, 60 (1980) (dictum).

35. 445 U.S. 55 (1980).

36. Id. at 65-68. The defendant in Lewis was convicted of violating 18 U.S.C. app. § 1202(a)(1)

(1976), a provision of the Gun Control Act of 1968. Section 1202(a) states in part:

Any person who-(1) has been convicted by a court of the United States or of a State or any political subdivision thereof of a felony . . . and who receives, possesses, or transports in commerce or affecting commerce . . . any firearm shall be fined not more than $\$ 10,000$ or imprisoned for not more than two years, or both.

For an analysis of the Gun Control Act, see Note, Prior Convictions and the Gun Control Act of 1968, 76 COLUM. L. REV. 326 (1976). For an analysis of the circuit court opinions that gave rise to Lewis, see Case Comment, The Use of Prior Uncounseled Convictions in Federal Gun Control Prosecutions: United States v. Lewis, 92 HARV. L. REV. 1790 (1979).

37. 445 U.S. 55, 65 (1980) (quoting Marshall v. United States, 414 U.S. 417, 422 (1974); McGinnis v. Royster, 410 U.S. 263, 270 (1973), and Baxstrom v. Herold, 383 U.S. 107, 111 (1979)).

38. 445 U.S. at 65 n.8.

39. Id.

40. Id. at 67 . The similarity between the firearm statute upheld in Lewis and the recidivist statute struck down in Burgett casts doubt upon Burgett and its progeny. Concededly, the statutes are not identical: the former statute imposes punishment for certain activities if the defendant has a prior conviction, 18 U.S.C. app. $\$ 1202$ (a)(1) (1976), while the latter statute increases punishment for certain activities if the defendant has a prior conviction, TEX. PENAL CODE art. 62 (1952). A simple hypothetical, however, demonstrates the difficulty of transforming this factual difference into a principled distinction. A legislature in a state that punishes driving in excess of fifty-five miles per hour with a fine could attempt to protect the public from those individuals who have outstanding drunk driving convictions (including convictions in violation of Gideon) by making it a felony punishable with imprisonment for those individuals to drive. Or the legislature could make it a felony punishable with imprisonment for those individuals to drive faster than fifty-five miles per hour. Despite the similar purpose and effect of the two hypothetical stautes, the first type of statute would be constitutional under Lewis while the second type of statute would be unconstitutional under Burgett. 
imposed. ${ }^{41}$ Under this view, the Sixth Amendment bars the collateral use of uncounseled convictions only when the government seeks to impose a criminal disability directly, or to enforce a non-criminal disability that is not rationally based on an uncounseled conviction.

\section{G. The Conflict}

The Lewis Court's view is inconsistent with earlier Sixth Amendment decisions. Lewis focuses on the government's interest in using uncounseled convictions, but never mentions the individual's Sixth Amendment interest in protecting himself from the collateral use of such convictions. The Lewis Court is thus willing to defer to the government's interest in the collateral use of prior convictions to "support guilt or enhance punishment" if that use is rational. ${ }^{42}$

In contrast, other opinions focus on the individual's interests and seek to prevent the erosion of his Sixth Amendment rights. These decisions shield the individual from any punishment that could not be directly imposed for an uncounseled conviction when the government seeks to support or enhance such a punishment through the collateral use of an uncounseled conviction. ${ }^{43}$ This approach protects the individual from all collateral uses of all uncounseled convictions except those convictions that are constitutional under Scott and those uses that do not support or enhance incarceration.

The only paragraph in Lewis that attempts to resolve the apparent conflict ${ }^{44}$ with earlier cases asserts that, in Burgett, Tucker, and Loper, the subsequent conviction or sentence depended on the reliability of the prior conviction, while in Lewis, the subsequent conviction depended only on the fact of the prior conviction. ${ }^{45}$ The Lewis opinion, however, did not

41. 445 U.S. at 67 (quoting Burgett v. Texas, 389 U.S. 109, 115 (1967)). Lewis held that the conviction was not unreliable for the purpose of imposing the firearm disability, id., which it found had met the requirement of a rational basis for the statutory distinctions made. Id. at 66 .

42. The Lewis opinion is similar to Scott in that it changes the meaning of the Sixth Amendment while explicitly accepting the results of earlier decisions. See supra p. 1003. Both cases limit the rationales supporting earlier Supreme Court rulings by finding government interests that preclude a particular extension of Sixth Amendment rights. Lewis differs from Scott, however, in its failure to offer a Sixth Amendment rule that is consistent with the results of other decisions.

43. See supra pp. 1003-1004.

44. Lewis explicitly accepted Burgett, Loper, and Tucker, and denied any inconsistency with those decisions. 445 U.S. 55, 60, 67 (1980).

45. 445 U.S. 55, 66-67 (1980). The Lewis Court defended its interpretation by emphasizing that Congress could rationally base its regulation of guns on the fact of a prior conviction, even an uncounseled and hence unreliable conviction. Id. The Court suggested that collateral use of uncounseled convictions had been prohibited in Burgett, Tucker and Loper because in those cases the Court found either that the government had not intended to use unreliable convictions or that use of such convictions was not rational. Id.

This suggestion is not borne out by the facts of those cases. Burgett was convicted of "assault with malice aforethought with intent to commit murder; repetition of offense," 389 U.S. 109, 110 (1967), 
explain why the convictions struck down in Burgett, Tucker, and Loper must be construed as depending on the reliability, rather than the fact, of the prior convictions. Moreover, the opinion fails to explain why the Sixth Amendment would require a more reliable prior conviction in those cases than in Lewis. ${ }^{46}$

Decided only two months after Lewis, Baldasar v. Illinois ${ }^{17}$ accentuates Lewis's inconsistency with Burgett. Baldasar held that an uncounseled misdemeanor conviction, though constitutional under Scott, could not

for violating a Texas statute that governs defendants who have been "convicted of the same offense, or one of the same nature." Id. at 111 n.3. The only prior conviction admitted into evidence was an outstanding uncounseled conviction. Burgett did not conclude that the Texas legislature intended to exempt from regulation individuals with allegedly uncounseled convictions or that the regulation of those individuals was irrational. Instead, the Court said that the Sixth Amendment prohibited use of an uncounseled conviction "to support guilt or enhance punishment for another offense." Id. at 115. Tucker and Loper also do not support the view that Sixth Amendment protection would not have been found to exist in those cases if the government had not depended on the reliability of the uncounseled convictions; instead the opinions suggest that such a finding might have made the Sixth Amendment violation a harmless error. Loper v. Beto, 405 U.S. 473, 483-84 (1972); United States v. Tucker, 404 U.S. $443,447-49$ (1972).

Burgett, Tucker and Loper not only cannot be distinguished in the manner suggested by Lewis, their opinions dictate a different result. Lewis's prior conviction was obtained in violation of Gideon, was necessary to establish his guilt under the gun law, and resulted in his punishment for a gun-law offense. This result is in direct contravention of a statement made in Burgett that "a conviction obtained in violation of Gideon v. Wainwright [cannot] be used against a person to support guilt or enhance punishment for another offense ..." Burgett v. Texas, 389 U.S. 109, 115 (1967). This statement is quoted in both Tucker, 404 U.S. 443, 449 (1972), and Loper, 405 U.S. 473, 481 (1972).

46. The Lewis Court's argument was augmented only by the claim that, unlike the situation in Burgett, the sanction imposed by the gun law attaches immediately upon the defendant's predicate uncounseled conviction. 445 U.S. 55, 67 (1980). The significance of this distinction, which the Court did not explain, seems tenuous: under both the recidivist statute in Burgett and the gun law in Lewis, the sanction of incarceration attached upon a conviction for violation of a criminal law that makes a prior uncounseled conviction an element of the crime.

In support of Lewis, it might be argued that the collateral use of an uncounseled conviction by the recidivist statute struck down in Burgett was very different from its use in Lewis. Violation of the recidivist statute in Burgett appears to require two guilty acts; hence, under the statute, an uncounseled conviction operated as a perfect substitute for a constitutional conviction. In contrast, the firearm statute in Lewis appeared consciously to use an uncounseled conviction only as a rational source of predictive information about an individual for legitimate regulatory purposes.

Both statutes, however, used the prior conviction to advance legitimate regulatory purposes and both cases decided the constitutionality of punishment for violation of the subsequent offense. If either statute punished the violation of both the prior conviction and the subsequent conviction, it would be invalid for double jeopardy reasons. Baldasar v. Illinois, 446 U.S. 222, 227 (1980) (Marshall, J., concurring). Another problem with this argument is that it would uphold recidivist statutes if they were rewritten so as to rely only on the fact of a prior conviction as a source of predictive information rationally used as a basis for statutory distinctions. A straightforward reading of Burgett would not allow its constitutional holding to be so easily skirted.

Lewis did not even attempt to show why Tucker or Loper should be construed to require a more reliable conviction than Lewis. Tucker, at least, cannot be construed to require a more reliable conviction than Lewis. Tucker held that the Sixth Amendment barred the consideration of an uncounseled conviction in sentencing decisions even though it stated that a judge may make a sentencing decision on the basis of almost any type of information. 404 U.S. 443, 446 (1972). Tucker considered the mistakenly presumed liability of the uncounseled conviction only to determine whether the sentencing error might have resulted in a different sentence, and hence whether the error was a reversible one. See id. at 448-49.

47. 446 U.S. 222 (1980). 
count as a predicate conviction for purposes of a recidivist statute. 4 Baldasar poses a strong challenge to Lewis because, unlike Burgett and Lewis, the collateral use challenged in Baldasar relied on a constitutional uncounseled conviction. Under Scott, such convictions may result in a criminal fine and in civil disabilities such as the loss of the right to vote or the loss of a professional license ${ }^{49}$-sanctions that are often more severe than the loss of the right to possess a gun. Because Scott allows a state to impose these sanctions, one might expect that a state would be permitted rational means of enforcing them, including incarceration. ${ }^{50}$ But Baldasar, in consonance with Burgett and seemingly in violent conflict with Lewis, ${ }^{51}$ held that even a constitutional uncounseled conviction could not support a subsequent conviction that results in incarceration.

Had Baldasar not followed Lewis, Lewis might reasonably be viewed as signaling a severe doctrinal shift, with the promise of later explanation. Together, the opinions present the appearance of a confused Court expounding conflicting doctrines. When the Court recognizes the conflict, it will have to overturn one or more decisions or adopt a new Sixth Amendment rule that is consistent with the results of all the cases.

\section{A Compromise Between the Competing Views}

This section proposes a rule that is a compromise between the competing views of the Sixth Amendment. The proposed rule is structured to accommodate both the values underlying the competing views and the actual holdings of the cases.

\section{A. Proposed Rule}

The proposed Sixth Amendment rule imposes three conditions for the

48. Id. at 224 .

49. See, e.g., AL $\Lambda$. CONST. art. $8, \S 182$ (conviction for specified types of crimes disqualifies one from voting); Bromberger, Rehabilitation and Occupational Licensing: A Conflict of Interests, 13 WM. \& MARY L. REV. 794 (1972); Duke, supra note 27, at 614-17; Project, supra note 27.

50. See Lewis v. United States, 445 U.S. 55, 60 (1980). Virtually the only direct sanctions for misdemeanor convictions in this country are imprisonment, fines, or a combination of the two. Thus, statutes often provide that defendants who do not pay a fine be imprisoned until the fine is paid or for a specified amount of time, and often punish the violation of a civil disability with imprisonment. E.g.,

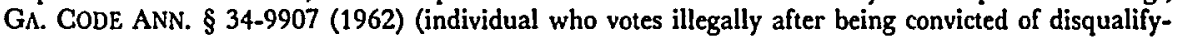
ing crime is guilty of misdemeanor punishable with incarceration); MISS. CODE ANN. \$§ 99-19-19, 99-13-11 (1972) (convicts to be imprisoned until fine is fully paid); see Williams v. Illinois, 399 U.S. 235, 246-59 app. (1970); Duke, supra note 27, at 614; Project, supra note 27, passim. It is not clear, however, whether a person may be jailed for failure to pay a fine if he has no means to pay. Tate v. Short, 401 U.S. 395 (1971) (equal protection clause forbids greater jail term for indigent's non-payment of fine than could be imposed directly for conviction resulting in fine).

51. The dissent in Baldasar points out that the conflict between the holdings of Lewis and Baldasar "could scarcely be more violent." Baldasar v. Illinois, 446 U.S. 222, 234 n.3 (1980) (Powell, J., dissenting). 
collateral use of an uncounseled conviction. First, it requires that independent constitutional rights not be infringed as a result of the use of an uncounseled conviction. Second, it allows the government to use an uncounseled conviction collaterally only if the government has no reasonable alternative. Third, the rule requires the government to provide access to an informal application process that can eliminate or modify the collateral use of an uncounseled conviction.

\section{Constitutional Rights Not Implicated}

Constitutional counseled convictions can be used collaterally to restrict certain constitutionally protected rights of affected individuals during and even after their punishment. ${ }^{52}$ Because uncounseled convictions are inherently unreliable, the proposed Sixth Amendment rule would not allow the government to use an uncounseled conviction collaterally in a way that directly restricts such rights. ${ }^{53}$ Regulations that are properly based on an uncounseled conviction, however, could be enforced with sanctions that restrict constitutional rights. Thus, an uncounseled conviction could not be used collaterally to restrict an individual's right to interstate travel, but punishment for a violation of a regulation properly based on an uncounseled conviction could include restrictions on the right to interstate travel.

\section{No Reasonable Alternative}

The proposed Sixth Amendment rule would proscribe the collateral use of uncounseled convictions unless the government can find no reasonable alternative method of advancing its interest ${ }^{54}$ that encroaches less on the interests of the individual defendant..$^{55} \mathrm{~A}$ court could find that no such reasonable alternative exists if all the alternatives are unacceptably costly in economic or other terms. The government would not be required to advance one interest to the exclusion of all other interests. Thus uncounseled convictions could be used if the government has no reasonable alternative means available to determine which individuals should be subject to

52. See Richards v. Ramirez, 418 U.S. 24 (1974) (state legislature allowed to prohibit individuals with outstanding counseled convictions from voting).

53. Cf. Gideon v. Wainwright, 372 U.S. 335, 343-44 (1963)(uncounseled conviction too unreliable for deprivation of fundamental rights).

54. Because the government's use of an uncounseled conviction infringes on significant interests, the use must have a fair and substantial relation to important government interests to satisfy equal protection guarantees of the due process clause.

55. Analogous constitutional rules govern government actions that infringe on constitutional rights such as freedom of speech and free exercise of religion. Such infringements are not allowed unless the government is pursuing the alternative that is the least restrictive of constitutional rights. For a discussion of these rules, see L. TRIBE, AMERICAN CONSTITUTIONAL LAW 410, 684-87, 846-59, 861 n.11 (1978). 


\section{the desired regulation..$^{56}$}

The government does not have the alternative of curing the deficiency ${ }^{57}$ of an uncounseled conviction unless the affected individual appeals the conviction. If the affected individual does successfully appeal, the government cannot constitutionally regulate his activities on the basis of the vacated or reversed conviction. ${ }^{58}$ Except in an unusual case, however, where the defect in the conviction affects the validity of the indictment, ${ }^{59}$ the person who successfully challenges his prior conviction can constitutionally be retried with counsel. ${ }^{60}$ The government can then regulate the individual on the basis of the indictment and any conviction that results. ${ }^{61}$

The proposed rule strikes a more effective compromise between governmental and individual interests. It permits the government to use uncounseled convictions collaterally when the government has no reasonable alternative. At the same time, because the government usually has a

56. Legislatures want to regulate certain classes of individuals because of rational assumptions about characteristics of members of those classes. Individuals who are, for example, minors, aliens, police officers, or accountants have special privileges and responsibilities.

The void for vagueness doctrine requires that membership in the regulated class can be reliably determined. See Lanzetta v. New Jersey, 306 U.S. 451, 453, 458 (1939) (holding statute unconstitutionally vague for making it illegal to be a "gangster"). Thus membership in a regulated group cannot be based on subjective criteria such as an individual's responsibility, intelligence, or specialized knowledge. Regulation must instead be based on indicators that positively correlate with the preferred criteria, indicators such as a criminal conviction, a test score, or a professional degree. A criminal conviction is often an irreplaceable indicator of certain characteristics a government wants to establish for purposes of regulation.

57. A government that wants to use an uncounseled conviction collaterally often does not have the alternative of providing counsel at the prior trial. See, e.g., Lewis v. United States, 445 U.S. 55, 56-57 (1980) (United States collaterally used Florida uncounseled conviction); United States v. Tucker, 404 U.S. 443, 444-46 (1972) (California proceeding collaterally used three of defendant's prior convictions from two other states where all three convictions violated Gideon standard that retroactively applied to them).

58. This issue has not been litigated, probably because the result would be clear. It would be irrational to allow a legislature to permanently subject an individual to regulation on the basis of a prior prosecution that culminated with the individual proving his innocence. A different conclusion would undermine the constitutional presumption of innocence. See Lewis v. United States, 445 U.S. 55, 61 n.5 (1980) (dictum); id. at 69 (Brennan, J., dissenting) (dictum); Note, supra note 36, at 334 \& n.42; infra note 61 .

59. If the indictment was irreparably defective or the prosecution was unconstitutional for violating protections such as double jeopardy or speedy trial rules, the indictment cannot be used and a new indictment cannot constitutionally be issued. See, e.g., Robinson v. Neil, 409 U.S. 505, 509 (1973) (conviction that violates double jeopardy protection cannot be retried); United States v. United States Coin \& Currency, 401 U.S. 715, 723 (1971) (conviction under statute that violates Fifth Amendment cannot be retried). Retrial would also be prohibited on double jeopardy grounds if the appellate reversal was based on a conclusion that the evidence at trial was insufficient to sustain a guilty verdict. Burks v. United States, 437 U.S. 1, 16-18 (1978).

60. Double jeopardy does not preclude the government from retrying a defendant whose conviction is set aside because of an error in the proceedings leading to a conviction. United States v. Tateo, 377 U.S. 463, 465 (1964); see, e.g., United States v. Wilson, 420 U.S. 332, 341 n.9 (1975); Forman v. United States, 361 U.S. 416, 425 (1960).

61. Regulation on the basis of an indictment is constitutional because of its practical necessity and its temporary nature. See Bell v. Wolfish, 441 U.S. 520 (1979). Such regulation is limited by the defendant's Sixth Amendment right to a speedy trial. 
reasonable alternative, the rule provides the individual considerable protection from the erosion of his right to appointed counsel and from further harm caused by an uncounseled conviction.

\section{Special Application Process}

Under the proposed rule, if the government has no reasonable alternative means of advancing its interests, it may use an uncounseled conviction collaterally, but only if it provides the convicted person with access to an informal application process that can prohibit or modify the use of the conviction. The government should be allowed to determine the nature of the application process as long as its decision is rational. ${ }^{62}$ To protect individuals from an arbitrary and capricious decision, or the appearance of one, the government's decisions should be explained, and judicial review should be available to ensure that the decision is not arbitrary and capricious. ${ }^{63}$

The burden of making an application process available discourages the government from allowing collateral uses of uncounseled convictions when its interest in such use is not great. In addition, the application process partially remedies the flaw in the judicial process created by the absence of counsel by preventing the government from automatically presuming that an uncounseled conviction is as reliable as other convictions. A defendant can insist that the government consider his interests and the circumstances of his prior conviction in evaluating the appropriateness of the conviction's collateral use. The particularized information that the individual can present forces the government to consider the individual's interests and discourages each collateral use that does not significantly advance government interests.

The cost of providing access to the required application process should not be unacceptably high. The proposed rule allows the government great discretion in formulating an application process when it wants to use an uncounseled conviction collaterally; presumably there will usually be an inexpensive alternative. Furthermore, most of the government's collateral uses of uncounseled convictions involve licensing or hiring procedures that already require it to process applications. ${ }^{64}$ In those situations the require-

62. For instance, it would presumably not be rational to provide an application process that requires the aid of an attorney, unless counsel is appointed for the indigent.

63. Cf. Dunlop v. Bachowski, 421 U.S. 560, $572-73$ (1975) (of right petition to Secretary of Labor for discretionary decision requires Secretary to issue "reasons" statement to assure careful administrative decision; judicial review available, decision reversible if arbitrary or capricious); Kitchens v. Department of Treasury, 535 F.2d 1197, 1199-1200 (1976) (application for discretionary relief from firearm disability requires "statement of reasons"; judicial review available, decision reversible if arbitrary or capricious).

64. See Project, supra note 27 , passim. 
ment of considering the circumstances of the uncounseled conviction should be a small burden. The few unlicensed activities the government would be allowed to regulate on the basis of an uncounseled conviction, and that the government has thus far shown an interest in regulating on the basis of prior convictions, often will not advance government interests sufficiently to justify both regulation consciously based on uncounseled convictions and the establishment of the required application process. In the remaining cases, the people who take the effort required to make a special application will probably not unduly burden the government.

Because an application could be made without the benefit of counsel, ${ }^{65}$ the right to an individualized determination of the appropriateness of the collateral use of an uncounseled conviction may be important to individuals who are sufficiently disadvantaged by the collateral use to apply for an exemption. The opportunity should be especially useful to individuals who have uncounseled convictions that cannot be reversed because they are constitutional under Scott or that cannot be reversed in time to prevent their collateral use. It should also benefit individuals who are able to use the informal application process provided by the regulating government but who are unable to appeal directly an unconstitutional uncounseled conviction because they were convicted in a distant jurisdiction or because they do not have the resources to make a judicial appeal. The right will not, however, help the many individuals who lack sufficient knowledge, foresight, or ability to use successfully an informal application process. ${ }^{66}$

All three of the proposed requirements guard against erosion of Sixth Amendment rights by limiting the government's opportunity to benefit from the prosecution of uncounseled indigent defendants and by limiting the circumstances under which the individual can suffer anew as a result of an uncounseled conviction. On the other hand, where no independent constitutional right is threatened, the requirements do not bar the government from advancing its interests.

Admittedly, the proposed line is not as clearly drawn as that in Scott. But unlike First Amendment rights that are often unacceptably chilled when the extent of constitutional protection is unclear, ${ }^{67}$ the Sixth Amend-

65. It should often be much easier to make an application in an informal forum in the jurisdiction that is imposing a disability on the basis of an uncounseled conviction than it would be to appeal the prior conviction in a court in the jurisdiction that imposed the conviction. This is especially true for those who live far from the jurisdiction that imposed the uncounseled conviction, who cannot afford to travel or hire a lawyer, and who want to remove a disability imposed by a government with local offices.

66. This problem is inherent in any Sixth Amendment rule that is consonant with Lewis, and is a strong argument for Lewis's reversal. It is also, unfortunately, a problem that permeates all rights and privileges that must be defended or secured through judicial or administrative proceedings. The problem, however, is smaller than it would be under the Lewis rationale. See supra p. 1012.

67. The Supreme Court has ruled that all applications of a vague statute that limits freedom of 
ment right to appointed counsel can be guarded through judicial scrutiny of the facts supporting the government's use of an uncounseled conviction. $^{68}$

\section{B. Applying the Proposed Rule to the Cases}

Lewis v. United States. The Lewis Court allowed Congress to advance its interest in prohibiting the possession of guns by what Congress rationally believed were particularly irresponsible classes of individuals, including the class composed of individuals with uncounseled convictions. ${ }^{69}$ The statutory scheme did not burden an independent constitutional right, ${ }^{70}$ and it gave individuals who were subject to regulation on the basis of an uncounseled conviction access to an application process that could remove their disability. ${ }^{71}$

Moreover, the alternative methods available to advance Congress' interests were arguably unsatisfactory. For example, Congress could have required everyone to apply for approval to possess a gun without infringing anyone's right to counsel. This alternative, however, was not a reasonable one for the courts to have mandated, because it would have required a totally different statutory scheme, one that was far more intrusive than necessary to fulfill Congress' interests.

The alternative of exempting from the gun law the relatively few individuals who have uncounseled convictions would have unduly restricted Congress in regulating what it rationally considered to be a dangerous activity. This alternative also might have undermined the effectiveness and logic of the statutory scheme through which Congress intended to regulate certain individuals' contact with firearms. Many individuals who other-

expression are unconstitutional because even a saving construction of the statute would be insufficient to eliminate the deterrence of protected expression. See Gooding v. Wilson, 405 U.S. 518, 521, 527-28 (1972).

68. The proposed Sixth Amendment rule would not allow a disability that restricts constitutional rights to be imposed on the basis of an uncounseled conviction. Hence possible uncertainty over whether a prior conviction is an uncounseled conviction would not chill the exercise of any constitutionally protected rights.

69. 445 U.S. at 66-67. The Court also noted that the gun law was not based on constitutionally suspect criteria. Id. at 65 n.8.

70. The Lewis Court noted that the gun law did not deprive the defendant of a constitutionally protected liberty on the basis of an uncounseled conviction, and suggested that it would have reached a different result if such a right was restricted. See 445 U.S. at 65 n.8.

71. Id. at 64; see Kitchens v. Department of Treasury, 535 F.2d 1197 (9th Cir. 1976) (decision of Treasury Secretary subject to judicial review); 18 U.S.C. app. $\$ 1203$ (2) (1976) (disability may be removed by qualifying pardon on consent of Treasury Secretary). The availability of the application process did not affect the constitutional right to appeal a prior unconstitutional conviction. See FLA. CONST. art. $5, \S 5$ (prior conviction may be reversed in coram nobis proceeding in Florida state courts); 28 U.S.C. $\$ 2254$ (1976) (federal habeas corpus relief may be available if state remedies are exhausted). The Lewis Court said that the existence of these sources of relief prevents the gun law from attaching irrevocable lifelong sanctions on the basis of an unreliable conviction. 445 U.S. at 64 n.7. 
wise clearly would have fallen within the terms of the statute would have been encouraged to forego available legal remedies for an unconstitutional uncounseled conviction and would have judged for themselves whether their prior convictions had had a deficiency that now exempted them from the gun law. Others might have claimed such a deficiency dishonestly, making enforcement of the laws more difficult. ${ }^{72}$

United States v. Tucker. The decision in Tucker ${ }^{73}$ barring the consideration of uncounseled convictions in sentencing decisions would not have been different under the proposed rule because there was a reasonable alternative to having judges consider uncounseled convictions in sentencing decisions, and because the defendant in Tucker had no access to the application process required by the proposed rule. Judges could have fulfilled the relevant sentencing objectives by considering only the factual evidence underlying the prior conviction-evidence untainted by the lack of counsel. ${ }^{74}$ Under the proposed rule, the government would be prohibited from introducing evidence of an uncounseled conviction to a sentencing judge

72. Cf. Brief for United States at 34-35, United States v. Lewis, 445 U.S. 55 (1980) (because of missing or incomplete records court may have to accept uncontroverted allegations of defendant regarding prior record). Several sections of the federal gun law limit the flow of firearms to restricted classes of individuals by requiring gun dealers to solicit and record detailed information about their customers and by prohibiting gun dealers from selling to anyone whom they have reasonable cause to believe may not lawfully receive a gun. See 18 U.S.C. $\S 922(\mathrm{c}),(\mathrm{d}),(\mathrm{m})$, (g) (1976). It would be much more difficult for gun dealers and police officers to check whether an individual has a prior counseled conviction than to check whether he has any outstanding conviction.

Exempting individuals with outstanding uncounseled felony convictions may also not be a reasonable alternative since some individuals would be strongly discouraged from appealing their convictions because a successful appeal might then expose them to regulation based on the newly outstanding indictment, see 18 U.S.C. $\$ 922$ (1976), and the possible valid conviction, 18 U.S.C. $\$ 1202$ (1976), that might result upon subsequent retrial. See supra p. 1010. Placing greater restrictions on individuals who successfully challenge their convictions than on those who leave their unconstitutional convictions intact, and thereby encouraging individuals to protect their unconstitutional convictions from reversal, is both illogical and contrary to the public interest. Moreover, burdening the full exercise of constitutional prerogatives may also create an independent constitutional violation. Cf., e.g., North Carolina v. Pierce, 395 U.S. 711, 724-25 (1971) (longer jail sentence upon retrial following successful appeal prohibited because it would chill exercise of basic constitutional rights); United States v. Jackson, 390 U.S. 571, 581-83 (1968) (clause in Federal Kidnapping Act that removes possibility of death penalty for defendants who waive right to jury trial prohibited for chilling exercise of basic constitutional rights).

73. 404 U.S. 443 (1972).

74. Evidence that is produced in violation of the defendant's right to appointed counsel is tainted and should not be considered in sentencing decisions because it would deprive the defendant of his Sixth Amendment rights in the same manner as the consideration of an uncounseled conviction. But as the Tucker Court pointed out, a sentencing judge is largely unrestrained in the kind of information he may consider or the source from which it may come. 404 U.S. at 446. The breadth of information that may be considered is illustrated by the fact that illegally seized evidence can be considered as long as it was not seized for sentencing purposes. See, e.g., Verdugo v. United States, 402 F.2d 599 (9th Cir. 1968); United States v. Schipani, 315 F. Supp. 253 (E.D.N.Y.), afTd, 435 F.2d 26 (2d Cir. 1970).

The defendant's Sixth Amendment rights will not be violated if the government introduces untainted factual evidence such as an arrest report because that evidence can be used whether or not the government seeks a conviction in proceedings that require the appointment of counsel. Furthermore, unlike an uncounseled conviction, an arrest report does not have a strong presumption of reliability, and judges are experienced in evaluating their reliability. 
unless the government could show that it made an unsuccessful, good-faith effort to find and submit untainted evidence. ${ }^{75}$ The proposed Sixth Amendment rule will have a similar application to revocation proceedings concerning a probation or parole restriction ${ }^{76}$ where the restriction stems from a constitutional counseled conviction. ${ }^{77}$

Loper v. Beto. The holding in Loper ${ }^{78}$ that an uncounseled conviction cannot be used to impeach a defendant's credibility is consistent with the proposed Sixth Amendment rule because the defendant there had no access to an application process that would permit him to challenge the government's use of the uncounseled conviction. Under the proposed rule, if the government does not have the reasonable alternative of impeaching the defendant with untainted evidence, it might be able to introduce evidence of an uncounseled conviction for impeachment purposes, but only if it provides access to an application process before the presiding judge. ${ }^{79}$ If it is a

75. This result is consistent with existing case law. Uncounseled convictions are not admissible in revocation proceedings, see, e.g., Cottle v. Wainwright, 477 F.2d 269, 273, 275 (5th Cir. 1973), vacated on other grounds, 414 U.S. 895 (1973) (unconstitutonal uncounseled conviction must be excluded from parole revocation, but constitutional uncounseled conviction may be used); Clay v. Wainwright, 470 F.2d 478, 479-84 (5th Cir. 1972) (probation revocation vacated where based solely on uncounseled conviction), but untainted evidence is admissible, see, e.g., Clay v. Wainwright, 470 F.2d 478, 479-84 (5th Cir. 1972) (rehearing of revocation proceeding without evidence of uncounseled conviction permitted); State v. Harris, 312 So. 2d 643, 644 (La. 1975) (uncounseled conviction or guilty plea cannot be used to revoke probation, but facts underlying conviction or guilty plea can be used); Alexander v. State, 258 Ark. 633, 636, 527 S.W.2d 927, 930 (1975) (uncounseled misdemeanor conviction punished only with fine cannot be used to revoke suspended sentence, but facts underlying conviction can be used by themselves).

76. Constitutional procedural requirements are the same for probation and parole revocation proceedings. E.g., Gagnon v. Scarpelli, 411 U.S. 778, 782 (1973); Van Dyke, Parole Revocation Hearings in California: The Right to Counsel, 59 CALIF. L. REv. 1215, 1241-43 (1971).

77. While Scott allows uncounseled misdemeanor defendants to be convicted and punished with probation restrictions, it does not allow them to be punished with imprisonment. Scott v. Illinois, 440 U.S. 367, 372-73 (1979). If the terms of probation are too severe, probation may be equated with imprisonment for purposes of the Scott rule. See S. KRANTZ, C. SMITH, D. ROSSMAN, P. FROYD, \& J. HOFFMIAN, RIGHT TO COUNSEL IN CRIMINAL CASES 31-32 (1976) [hereinafter cited as S. KRANTZ]; cf. Jones v. Cunningham, 371 U.S. 236 (1963) (severe parole requirements equated with custody for habeas corpus purposes); United States v. Kentucky, 372 F.2d 641 (2nd Cir. 1965) (severe probation requirements equated with custody for habeas corpus purposes). Knowing this, the prosecuting government can appoint counsel for indigent misdemeanor defendants who have not waived their right to counsel in cases where the government believes it may want to incarcerate the defendant for the crime charged. If this alternative is not utilized, the government is barred from incarcerating the individual for the original misdemeanor conviction as a result of a probation violation. See supra p. 1002; Baldasar v. Illinois, 446 U.S. 222, 222, 224, 226-29 (1980); S. KRANTZ, supra, at 35-37. Even if Scott and Baldasar were not construed to prohibit incarceration for a violation of probation for an uncounseled misdemeanor conviction, it would be illogical to reach a different result. Since probation requires the consent of the defendant, the uncounseled defendant could eliminate any chance of incarceration by refusing any probationary offer. If the act that violates probation is independently illegal, the defendant can be separately prosecuted and punished for that crime.

78. 405 U.S. 473 (1972).

79. An example of a circumstance in which the presiding judge might want to allow the collateral use of an uncounseled conviction is when the conviction could be used for the purpose of directly rebutting a specific false statement made from the witness stand (such as a statement that the defendant had never been convicted of a felony). See Lewis v. United States, 445 U.S. 55, 66-67 (1980); Loper v. Beto, 405 U.S. 473, $482 \mathrm{n.11}$ (1972) (plurality opinion). If the defendant's statement can be 
jury trial, the jury must be shielded from the application process so that the result of the process is meaningful. ${ }^{80}$

The proposed Sixth Amendment rule's first constitutional requirement also might not have been met in Loper because the admission into evidence of a potentially unreliable uncounseled conviction for purposes of impeachment might have been unnecessarily prejudicial, thus violating the defendant's independent constitutional right to due process ${ }^{81}$ or to an impartial jury. ${ }^{82}$ The same considerations of fundamental fairness apply to both these rights. ${ }^{83}$ The courts have determined the degree of protection afforded by these rights by balancing the defendant's interest in an unbiased jury against the state's interest in protecting the public and providing accurate adjudication. ${ }^{84}$ While the extension of these independent constitutional protections to a defendant with a prior counseled conviction might be outweighed by the probative value of that conviction, ${ }^{85}$ the proposed Sixth Amendment rule would not allow a reduction for a defendant with an uncounseled conviction. If these independent constitutional rights were infringed, the proposed Sixth Amendment rule would have prohibited the collateral use of the uncounseled conviction for purposes of impeachment.

Burgett v. Texas and Baldasar v. Illinois. The proposed rule also leaves Burgett and Baldasar intact. Governments have a reasonable alternative method of satisfying the purposes of a recidivist statute without imprison-

rebutted without reference to the uncounseled conviction, however, the rule would still bar its use. Evidence of a prior indictment, for instance, would sometimes be a reasonable alternative.

80. Research indicates that juries do not follow instructions concerning the proper use of information about a defendant's criminal record, see H. KALVEN \& H. ZEISEL, THE AMIERICAN JURY 127-30, 160 (1966) (knowledge of defendant's prior criminal record significantly affects jury deliberations); Note, To Take the Stand or Not to Take the Stand: The Dilemma of the Defendant With a Criminal Record, 4 COLUM. J.L. \& SOC. PROBS. 215, $217-18$ (1968) (98\% of attorneys and 43\% of judges responding to survey concluded that jurors cannot understand or follow courts' limiting instructions on use of defendant's prior criminal record), and that a defendant is more likely to be convicted if the jury is informed of his record. H. KALVEN \& H. ZEISEL, supra, at 160, 177-81; Project, supra note 27, at 1046-47 \& nn. 848-49.

81. U.S. CONST. amends. V, XIV; see Project, supra note 27, at 1048 \& n.862; Note, supra note 36, at 346-49; Note, Constitutional Problems Inherent in the Admissibility of Prior Record Conviction Evidence for the Purpose of Impeaching the Credibility of the Defendant Witness, $32 \mathrm{U}$. CIN. L. REV. 168, 173-80 (1968); Note, The Limiting Instruction-Its Effectivensss and Effect, 51 MINN. L. REV. 264, 287 (1966).

82. U.S. CONST. amend. VI; see Project, supra note 27, at 1048 \& n.861; Note, supra note 36, at 346; Note, Constitutional Problems, supra note 81, at 173-80; see also Note, The Limiting Instruction, supra note 81, at 286 (Supreme Court "has never interpreted the Sixth Amendment to apply to evidentiary practices which might periodically influence jurors," but it "would not be stretching the meaning of . . . 'impartial' to preclude the introduction of other crimes' evidence prior to a finding of guilt or innocence").

83. Note, supra note 36 , at 346-48 \& n.119; see, c.g., Groppi v. Wisconsin, 400 U.S. 505, 509 (1971); Baker v. Hudspeth, 129 F.2d 779, 781 (10th Gir. 1942), cert. denied, 317 U.S. 681 (1942).

84. See, e.g., People v. Laskowski, 166 Misc. 640, 644, 3 N.Y.S.2d 98, 102 (1938); Note, supra note 36 , at 347 \& n.122, cf. Irwin v. Dowd, 366 U.S. 717, 722-23 (1961) (defendant's right to impartial jury limited by practical considerations-minor jury preconceptions acceptable).

85. See Project, supra note 27, at 1048 \& n.863; Note, supra note 80 , at 219-20. 


\section{Uncounseled Convictions}

ing people for convictions supported by prior uncounseled convictions. ${ }^{86}$ Rather than imposing special regulations solely on the basis of an uncounseled conviction, the legislature, as suggested in Tucker, ${ }^{87}$ could have given judges enough sentencing guidance and discretion so that they could have imposed punishments that reflected their knowledge about the individual defendant.

\section{Conclusion}

The rule proposed by this Note strikes a compromise between Lewis and the Supreme Court's other Sixth Amendment decisions, while leaving all the existing cases intact. The rule seeks to protect the most important government and individual interests with respect to collateral uses of uncounseled convictions, to discourage collateral uses where the government interest is not great, and to provide the individual with a remedial procedure when an uncounseled conviction is used.

86. The recidivist statutes are also constitutionally suspect because of their particularly severe encroachment on the right to appointed counsel. Under the statutes at issue, individuals regulated on the basis of uncounseled convictions could only remove their disability by appealing their convictions. See ILL. REV. STAT. ch. 38, § 16-1(c) (1974); ILl. REV. STAT. ch. $38 \S \S 1005-8-3$ (a)(1),-1(b)5, (c)(5) (1975) (statutes that resulted in Baldasar conviction for recidivism); TEX. PENAL CODE art. 62 (1932) (recidivist statute that resulted in Burgett conviction). This problem is not easily remedied because an individual presumably could not remove his disability by establishing through an application that presumptions about the class of individuals he is grouped with should not be applied to him individually. Since the specially regulated activity is already illegal for everyone, it would be ridiculous for an individual to apply for reduced sanctions for committing future illegal acts on the ground that presumptions about his potential threat to society are false.

87. See United States v. Tucker, 404 U.S. 443, 446-47 (1972); supra p. 1014. 